\title{
Building Relationships of Brand Community in Higher Education: A Strategic Framework for University Advancement
}

Received (in revised form): February 1, 2006

\section{James H. McAlexander}

James H. McAlexander is Professor of Marketing in the College of Business at Oregon State University, Corvallis, OR 97331, USA.

\section{Harold F. Koenig}

Harold F. Koenig Associate Professor and Coordinator of the Marketing Program in the College of Business at Oregon State University, Corvallis, OR 97331, USA.

\section{John W. Schouten}

John W. Schouten is Associate Professor at the University of Portland. McAlexander and Schouten are co-founders of Ethos Market Research.

\begin{abstract}
Loyal alumni are a mainstay of financial support for many universities. This empirical study of university alumni situates the emerging theory of brand community within the world of university development and advancement. The study measures key relationships that one would expect to find in a healthy university brand community. Most importantly, this research demonstrates the powerful contribution that understanding and managing brand community can make
\end{abstract}

Author's Contact Address:

James $\mathrm{H}$. McAlexander

Oregon State University College of Business

Box 408, 200 Bexell

Corvallis, Oregon

Phone: +541737 3182 (office)

Fax: +5417374890

E-mail: mcalexan@bus.oregonstate.edu to those interested in the advancement of higher education. We find that integration within a university brand community explains important loyaltyrelated behaviors such as future donations to the university and the purchase and display of university logo merchandise.

International Journal of Educational

Advancement (2006) 6, 107-118

doi:10.1057/palgrave.ijea.2150015

Keywords:

branding, higher education marketing, institutional advancement

\section{Introduction}

In higher education, we often extol the virtues of membership or participation in our "academic communities." In 
using the term community, we acknowledge special characteristics of our experiences in academia. As members of academic communities we are interdependent. We have common goals and values. We identify with specific localities and institutions with levels of pride and occasional chagrin that reveal the depth of their meaning in our lives. We support and nurture fellow community members as we share meaningful ideas and experiences. In addition to the regular denizens of university campusesstudents, staff, and faculty-we also recognize our interdependence with other members of a broader academic community that includes alumni, parents, prospective students, businesses, fans of our athletic teams, and others who engage with our universities in various ways.

The lexicon of community nicely complements the interests of development officers, alumni relations directors, and others who work to build support for higher education. Terms and expressions such as interdependence, affiliation, sharing, and common goals and values suggest a wealth of opportunity for advancement professionals. Beyond such feel-good semantics there exists a growing body of evidence indicating that certain collectives, which marketing professionals call brand communities, grounded in overlapping interests in a branded product, service, or institution can be nurtured and managed strategically to benefit those institutions. This paper presents an empirical study that explores the applicability of the brand community construct among university alumni and its relevance to important challenges of advancement.

\section{Brand Community and its Component Relationships}

Let us begin by asserting that a university is a marketing institution that offers a broad range of products and services to an equally broad range of consumers through many outlets and service providers under the auspices of its brand. Once we accept the idea of the university as the steward of a brand, the implications of a brand community are especially intriguing.

The construct of brand community has emerged from a growing appreciation for the powerful influence that social dimensions of customer experience assert on focal marketing concerns such as satisfaction and loyalty (Fournier, 1998; Holt, 1995; Schouten and McAlexander, 1995). Muniz and O'Guinn (2001) describe a brand community as the product of social relationships among users of a brand, regardless of their geographical location, who recognize their commonality and who share rituals, traditions, and a sense of responsibility toward the brand. Holding to this definition, a sampling of the home addresses of people attending any university homecoming should suffice to demonstrate the existence of a widespread university brand community.

McAlexander et al. (2002) have conceptualized and empirically tested a more comprehensive model of brand community, which they characterize as a web of relationships that connect customers to a brand and, under its umbrella, to its products and services, its associated institution, and its other customers (see Figure 1). They go on to 
THE BRAND COMMUNITY

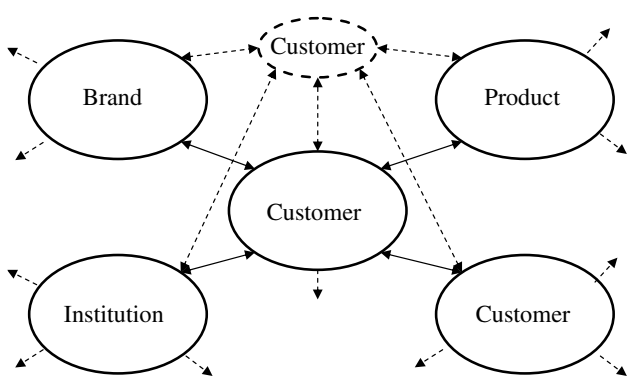

Figure 1: The brand community

demonstrate that strong brand community relationships indicate integration within the community, greater customer loyalty, and all the behaviors that customer loyalty implies, including increased positive word-of-mouth, intent to repurchase, and receptiveness to brand extensions. Finally, their research supports the hypothesis that a brand community can be cultivated and strengthened.

In this paper, we discuss the various component relationships of a brand community, contextualize them to higher education, and test the overall model of brand community integration with alumni of a major Western university.

\section{The customer-product} relationship: My education and I To marketers of tangible goods, the customer-product relationship often is readily visible. We can observe a child's affection for a stuffed animal or an enthusiast's adoration of an automobile. In education, our core product, the development and transfer of knowledge, is largely intangible. You cannot hug or polish an education. Nonetheless, educators regularly measure elements of this dimension of brand community. For example, we assess student and alumni perceptions of the quality of their educations and their satisfaction with the educational experience in hopes of improving our own performance. Although we do not as often research such things as the relationship of education to the self, we often hear students and alumni report how their educations have profoundly impacted their lives and their identities. Our education becomes an integral part of our identity, which constitutes one of the most meaningful relationships a person can have with an object, person, experience, or concept (Belk, 1988). The more centrally and positively a person's education figures in her identity, the more attached she is likely to be to the source of that education. The brand community model used herein measures the individual's perceived identity connection with her university education as one component of her integration in a university brand community.

The consumer-brand relationship: Proud to be a fighting banana slug The value and the meanings customers derive from brands are core concerns for marketers, especially as they seek to build brand equity. Through positioning strategies marketers strive to communicate consistent and resonant brand messages with their target audiences. Beyond simple positioning, marketers have increasingly turned to relationshipderived models and language to build stronger brands (Aaker, 1996; Fournier, 1998). The connections 
consumers form with brands derive from utilitarian benefits as well as symbolism that communicates important information about them to themselves and to others. Emotional connections to brands are especially valuable in motivating continued ownership (Gardner and Levy, 1955; Grubb and Grathwohl, 1967; Aaker, 1996; Keller, 1998).

Many university administrators have traditionally avoided viewing themselves as marketers or brand managers. With growing frequency, however, universities recognize the opportunities that can come from engaging in marketing activities and taking a more proactive approach to understanding and shaping the meaning of the university brand. University marketers and advancement officers now commonly speak of the importance of understanding and managing the personality or identity of their institutions. In order to accomplish particular positioning statements, advertising expenditures are being increased, as are investments in logos, mascots, student activities, and facilities. The apparent expectation is that these investments will build stronger relationships with customers who are proud to display their university colors. Progress in building customer-brand relationships is visible in the increasing frequency in which students, employees, alumni, and friends adorn themselves, their cars, their offices, and their homes with university-logo-branded merchandise. The personal connection that can be developed with the university brand and its personality is an important component of integration within the brand community.

\section{The customer-institution} relationship: Service please

A most powerful way in which an institution can build a relationship to its customers is through the connections that can develop between the customers and the institution's representatives (Bitner, 1995; Dwyer et al., 1987; Hartline and Ferrell, 1996; Price and Arnould, 1999). This type of interpersonal relationship has obvious implications for service quality. More than any other relationship in the brand community, the one between the customer and the institution stands to benefit from the laws of reciprocity (Sherry, 1983), which basically hold that largesse begets largesse. When an institution, through one of its agents, does more for a customer than that customer expects, there often ensues a desire on the part of the customer to return goodwill upon the institution.

McAlexander and Koenig (2001) have documented positive effects of the customer-institution relationship in higher education. College students and alumni form relationships with many institutional representatives. These can be as seemingly inconsequential as transactional interactions (e.g., a onetime interaction with a food service employee in the cafeteria) to apparently more meaningful long-term relationships (e.g., students and their academic advisors or favorite professors). In the aggregate, interpersonal relationships with the university's agents can enhance or erode feelings of connection to the institution. Naturally, the initial level of customer expectation makes a difference in the perceived quality of interaction with the university. An institution that positions itself as small and nurturing will need to clear a 
higher bar than one that is known as a research mill. The brand community model measures the perceived quality of relationships between an individual and agents of the educational institution as a contributor to integration in the brand community and an indicator of key loyalty behaviors.

\section{The customer-customer relationship: My tribe}

Marketers appreciate the impact of word-of-mouth communications on buyer behavior, but they have only recently begun to explore the manner in which relationships among customers influence the experiences of ownership and product use. Peers or other reference groups can motivate the initial purchase of a product or service, or alternatively, shared benefits can accrue with time and experience in ways that profoundly impact loyalty (Schouten and McAlexander, 1995). Arguably, relationships among customers are more fundamental to the existence of a brand community than any other type of customer relationship (Muniz and O'Guinn, 2001).

In the setting of higher education, casual observation quickly reveals the existence of important social groups. Students form diverse affiliations within the community as they ally themselves with others that share their psychographic profiles. The foundations of affiliation include such things as major academic interests, political persuasions, and preferred recreational pursuits. Whether through living groups (such as dorms, shared apartments, fraternities, and sororities), chat rooms, classroom discussions, or athletic and cultural events, students have opportunities to interact with one another and form connections that resemble other consumer collectives. Many build bonds that last a lifetime. McAlexander et al. (2004) have documented the marketing impact of interpersonal relationships in higher education. What remains is to assess the collective impact of all the foregoing types of relationships on key indicators of loyalty and support for the university.

\section{The university experience and} brand community integration Marketers have a long and varied history of examining the individual relationships that weave through a brand community. The concept of brand community integration (McAlexander et al., 2002) suggests there is significant value in looking at these various dyadic relationships collectively. McAlexander et al. (2002) find that when properly managed, such relationships can build synergistically. Their research indicates, for example, that consumer interaction with a product or service, especially in personally challenging or meaningful situations, can lead to extraordinary and even transcendent experiences (McAlexander and Schouten, 1998; Schouten et al., 2005). Those experiences create favorable impressions of the brand, which in turn can be reinforced through interaction with other customers and with marketers. Moreover, all of these relationship-forming opportunities can be facilitated and managed by the marketing institution.

We can observe such synergies in the higher education environment. A trip to the college computer lab or the 
library during finals week reveals students working together in stressful situations to co-create the product that is their education. Instrumental to their success are the mentoring opportunities provided by faculty, graduate assistants, and advisors. Less stressful, but perhaps more exciting, a visit to a fall football game finds students cheering in unison for their university's team with an expectation that their collective effort will have an impact upon the game's outcome. These types of experiences, like those provided by marketers in industry (cf., Arnould and Price, 1993; Celsi et al., 1993; Holt, 1995; McAlexander and Schouten, 1998), provide opportunities for building the university brand community in synergistic ways. Next we examine empirically the viability of the brand community construct in the academic setting and its relationship to behaviors commonly associated with brand loyalty.

\section{Present Study}

The goal of this study was to determine empirically if the brand community construct is relevant to higher education, and if it is, to examine the impact of integration in a brand community on the types of loyalty-related outcomes that university advancement professionals might seek. Specifically, we investigated whether alumni's university experiences created significant perceived relationships with the product (their education), the brand (including the university name, logos, mascots), the institution (agents such as faculty and staff), and other alumni, and how the collective influence of those relationships would impact loyalty outcomes like current behavior (e.g., wearing university logo clothing) and behavioral intentions (e. g., future donations). We approached the problem with several hypotheses.

Our first goal was to determine if the four-part brand community model, found in the market for charismatic brands and highly involving consumer durables, has relevance for higher education.

$\mathrm{H}_{1}$ : An acceptable fit for a four-part brand community model will be found using confirmatory factor analysis.

The next step was to determine if an acceptable second-order model (brand community integration) could be created from the four-part brand community model. The issue is whether the four parts work together (i.e., covary) sufficiently to be integrated into one construct.

$\mathrm{H}_{2}$ : An acceptable fit for a secondorder model will be found using a structural equations model.

If a successful second-order model was found, what impact would a brand community have in a university setting? To answer this, a variety of items in the survey measured current behavior and behavioral intentions.

$\mathrm{H}_{3}$ : A significant amount of the variance in measures of current attitudes and behavior related to loyalty will be explained by brand community integration.

$\mathrm{H}_{4}$ : A significant amount of the variance in measures of loyaltyrelated behavioral intentions will be explained by brand community integration. 
Our measures were adapted to the current setting from prior research on brand community in the automotive industry (McAlexander et al., 2002). For example, when considering the customer-product relationship, rather than asking about relationships with a vehicle we made inquiries regarding skills and abilities acquired at school and the degree to which the university education is deemed to be incorporated into sense of self.

Alumni who had graduated from a college within a large university in the Western United States (West U.) between three and ten years before the date of the study were the target population for a telephone survey. An appropriate list of alumni was obtained from the university alumni office. The goal of the survey was to produce between 450 and 550 usable surveys, and a systematic sample that allowed for replacement names was drawn from the list. When phone numbers were not given on the list, interviewers were instructed to call information, or check residential listings on the internet, to find numbers. When a number was located, and no one answered or an answering machine picked up, interviewers made five attempts before obtaining a replacement.

Contacts were attempted for a total of 1,673 alumni in late January and early February of 2002. Four hundred and ninety-seven completed surveys were collected for a response rate of 30 percent. When nonresponses were tabulated, the largest single category was "no listing available, untraceable," which contained a total of five hundred and thirty-seven alumni names-clearly this was a contributing factor to the low response rate.

\section{Measurement}

On the basis of the brand community model, we measured the following four customer-centric relationships: alumni/ product, alumni/brand, alumni/ institution, and alumni/other alumni. All items were measured with a sevenpoint Likert-type scale, anchored by (1) strongly disagree and (7) strongly agree.

The alumni/product relationship was measured with five items designed to capture the alumni's feelings about their degree, skills, and abilities learned at West U., and items assessing whether the degree formed part of their extended self. The alumni/brand relationship was measured with five items that assess the alumni's connection with the university brand position and such things as the mascot. The alumni/ institution relationship was measured with five items that capture the feelings alumni have about the institution (e.g., the level of the college's concern for students) and the individuals, like professors, with whom they spent significant "face time" during their student years. The alumni/alumni relationship was measured with two items that capture the feelings of alumni about other alumni of the college.

\section{Analysis and Results}

An initial check of the reliability and unidimensionality of the survey items reveals that all but one exceeded Nunnally's (1978) guideline for reliability (the alpha for Institution was 0.69), and all were judged as unidimensional based on the eigenvalues obtained from factor analysis. 
The survey items that correspond to the four customer-centered relationships were then tested in a four-factor confirmatory model. An acceptable fit was achieved $\left(\chi^{2}\right.$ $(84 \mathrm{df})=303.92(P=0.0), \mathrm{GFI}=0.927$, $\mathrm{RMR}=0.098, \mathrm{NFI}=0.867, \mathrm{CFI}=0.899$ ) using the Gerbing and Anderson (1988) procedure, providing support for Hypothesis 1 . In this process, two items were eliminated (one from Brand and one from Institution); this change had a negligible impact on the substantive content of the affected dimensions. Using the LISREL results, the reliabilities for the factors (Fornell and Larcker, 1981) were checked again. Institution was again at the margin (0.69), but the two-item scale for Other alumni scored only 0.55.

The next step was to assess whether these four constructs were an adequate reflection of a single higher-order construct. For this purpose, a secondorder factor structure was tested (see Figure 2), and an acceptable fit for this model was found (Table 1), providing support for Hypothesis 2. The CFA and the second-order model provide evidence of two important points: first, each dimension has acceptable measurement properties and is distinct from the other dimensions, and second, they can be combined to form one higher-order construct.

To better understand the impact of brand community in a university setting, a series of regressions was run with brand community integration as the independent variable. Single item measures were included in the survey to assess the current attitudes and behavior, as well as behavioral intentions, of the alumni.

In the set of current attitudes and behaviors, all of the regressions are statistically significant, providing support for Hypothesis 3. The $\mathrm{R}^{2}$ values for the regressions, which used brand community integration as an independent variable to assess how much variance could be explained in the current attitudes and behaviors, ranged from 0.23 to 0.42 (see Table 2 ). The lowest explained variance was for the alumni's report of wearing West U. logo clothing, where only 23 percent of the variance was explained, while the explained variance in the item "I really like West U." was over 42 percent.

In the set of behavioral intentions, all the regressions were statistically significant, providing support for Hypothesis 4. The item which assessed if the alumni would like to come back to West U. for continuing education was the lowest, with under 10 percent of the variance explained by Brand community (see Table 2). The other three items, sending children to West U., the desire to participate in an alumni group, and the possibility of making a donation to West U., all had explained variance between 27 and 30 percent.

\section{Discussion and Application}

Prior research demonstrating the benefits of brand community has addressed communities formed around highly engaging activities and charismatic brands, including HarleyDavidson motorcycles, Jeep vehicles, Apple computers, sports cars, and bicycles (Baker and Martin, 2000; Muniz and O'Guinn, 2001; McAlexander et al., 2002; Dodson, 1996). Current research demonstrates that higher education can also evoke and benefit from the valued qualities of brand community that are 


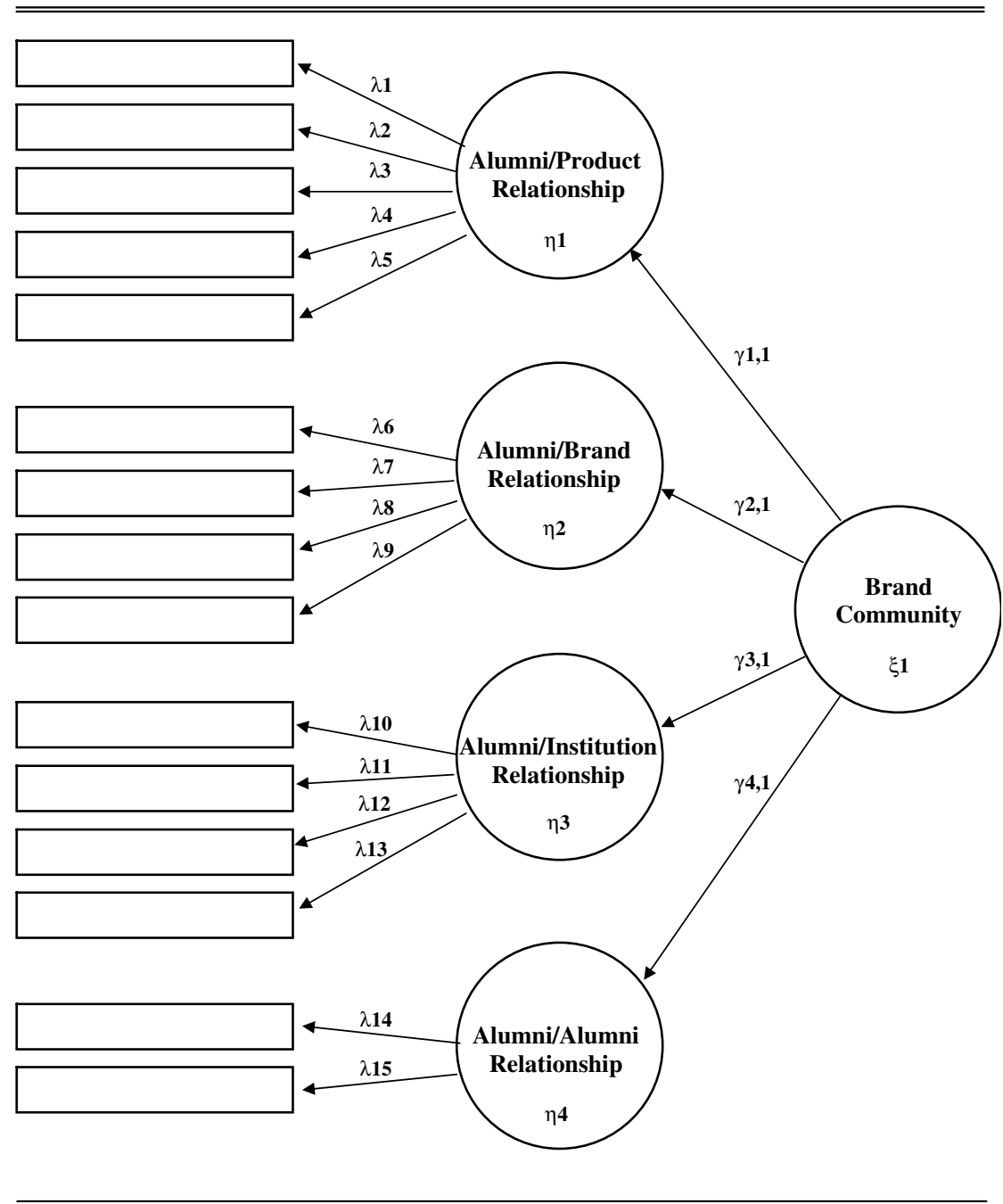

Figure 2: Two-stage model of brand community

associated with these brands and products. This study shows that integration in a brand community in higher education can contribute to such valued behaviors as donations, college referrals, engagement in alumni groups, and participation in continuing education. These are the outcomes that are sought by those professionals who share the responsibilities of marketing and advancement in higher education.
A most important implication of this research is the demonstration of the strategic value that comes from viewing a university's connections with its students and alumni both broadly and holistically. Traditional approaches to interactions with alumni that neglect the diverse connections that form a university brand community may be shortsighted and result in lost opportunities. It is important to 
Table 1: Standardized lisrel estimates ${ }^{\mathrm{a}}$ for the second-order model

\begin{tabular}{|c|c|c|c|c|}
\hline Indicator & Alumni/product & Alumni/brand & Alumni/institution & Alumni/other alumni \\
\hline \multicolumn{5}{|c|}{ First-order loadings ( $\lambda y)$} \\
\hline Alum/Prod1 & $1.067(15.10)$ & & & \\
\hline Alum/Prod2 & $0.512(11.90)$ & & & \\
\hline Alum/Prod3 & $0.596(8.31)$ & & & \\
\hline Alum/Prod4 & $1.190^{\mathrm{b}}$ & & & \\
\hline Alum/Prod5 & $0.955(15.46)$ & & & \\
\hline Alum/Brd1 & & $1.009^{\mathrm{b}}$ & & \\
\hline Alum/Brd2 & & $0.946(11.53)$ & & \\
\hline Alum/Brd3 & & $0.980(14.00)$ & & \\
\hline Alum/Brd4 & & $0.822(12.72)$ & & \\
\hline Alum/Inst1 & & & $0.831(9.77)$ & \\
\hline Alum/Inst2 & & & $0.857^{\mathrm{b}}$ & \\
\hline Alum/Inst3 & & & $0.849(9.35)$ & \\
\hline Alum/Inst4 & & & $0.728(6.90)$ & \\
\hline Alum/Alum1 & & & & $1.299^{\mathrm{b}}$ \\
\hline Alum/Alum2 & & & & $0.566(7.75)$ \\
\hline \multicolumn{5}{|c|}{ Second-order loadings ( $\gamma j k)$} \\
\hline & & \multirow{2}{*}{\multicolumn{2}{|c|}{$\begin{array}{l}\text { Goodness-of-fit statistics } \\
\chi^{2}(86 \mathrm{df})=330.12(P=0.0)\end{array}$}} & \\
\hline First-order construct & Brand community & & & \\
\hline Product & $0.777(14.27)$ & \multicolumn{3}{|c|}{ Goodness-of-fit index $(\mathrm{GFI})=0.920$} \\
\hline Brand & $0.939(15.26)$ & \multicolumn{3}{|c|}{ Root mean square residual $(\mathrm{RMR})=0.109$} \\
\hline College & $0.690(10.19)$ & \multicolumn{3}{|c|}{ Normed fit index $(\mathrm{NFI})=0.855$} \\
\hline Other alumni & $0.716(13.02)$ & \multicolumn{3}{|c|}{ Comparative fit index $(\mathrm{CFI})=0.888$} \\
\hline
\end{tabular}

${ }^{\mathrm{a}} t$-values in parentheses

${ }^{\mathrm{b}}$ Fixed parameter

understand that attempts to manage a single dimension of brand community can have implications that ripple through the community. Synergy can be found by understanding the collective interactions and impacts that come from building the brand, strengthening the product, connecting alumni, and cultivating bridges to the institution. The professionals engaged in building meaningful programs in executive or continuing education can benefit from coordination with development officers who seek to foster relationships between alumni and the institution and its academic programs. University marketers who seek to build the university brand can derive benefits from the efforts of alumni associations that look to build interpersonal relationships among graduates. The construct of brand community integration provides a means for drawing together these diverse connections in a way that has the power to offer insights into building stronger bonds and understanding or diagnosing those that exist.

To university marketers and advancement professionals, another important observation from our research is the insight that the time to begin forming "alumni relationships" 
Table 2: Regression results with brand community as the independent variable

\begin{tabular}{lcclcc}
\hline Dependent variable & $R^{2}(\mathbf{\%})$ & F & Significance & Beta & $t$ \\
\hline Really like West U. & 42.2 & 325.82 & 0.000 & 0.649 & 18.05 \\
Wear logo clothing & 23.3 & 135.66 & 0.000 & 0.483 & 11.65 \\
Recommend West U. & 33.7 & 227.15 & 0.000 & 0.580 & 15.07 \\
Enjoy talking about West U. & 41.8 & 321.44 & 0.000 & 0.647 & 17.93 \\
Very satisfied West U. & 37.3 & 265.36 & 0.000 & 0.610 & 16.29 \\
experience & & & & & \\
Continuing ed. at West U. & 9.7 & 47.92 & 0.000 & 0.312 & 6.92 \\
Kids to West U. & 27.4 & 167.97 & 0.000 & 0.524 & 12.96 \\
Could donate to West U. & 30.6 & 196.78 & 0.000 & 0.553 & 14.03 \\
Like to be involved in & 29.0 & 182.22 & 0.000 & 0.539 & 13.50 \\
alumni group & & & & & \\
\hline
\end{tabular}

is not when students are alumni, but rather when they are in school. Efforts toward building community, such as sponsoring events, offering student liferelated activities, facilitating interaction with faculty, and establishing brand identity with current students, offer the potential of enduring alumni loyalty. Postgraduation efforts, by themselves, may not be as well received without the early effort to establish community while the students are on campus.

The limitations of this study are many, including those that are typical of survey research. Our research was based on a sample of a specific college within a particular university; consequently, generalizing from our findings should be done with caution. Of particular interest, as suggested by Price and Arnould (1999) in recent work that demonstrated the importance of contextual influences to relationship formation, future research would be valuable in nontraditional educational settings (distance education) and to other service settings.
Given that this is a study of a single university, administrators of other universities may be well advised to determine the desirability and nuances of a university brand community to their students and to their competitive positioning. Prior work regarding consumer collectives reveals distinctive subtleties of communities as they form in association with different brands, products, and services (cf., Holt, 1995; Muniz and O'Guinn, 2001; Schouten and McAlexander, 1995). To successfully build brand community requires an empathic understanding of customers' needs, desires, values, and behaviors. A successful brand community is one that acknowledges essential values of the community and presents value to its members that is in reasonable balance with the desires of the institution (see Fournier, 2001).

In summary, the value proposition of building a vital university brand community is this. Integration in the brand community creates enduring bonds of loyalty to the institution. That loyalty yields returns in terms of 
support for the university, its products, and its programs. A brand community can be nurtured and strengthened by the institution. The model presented here may provide the necessary tools university marketers need to diagnose, track, and build the component relationships of a university brand community.

\section{References}

Aaker, D.A. (1996), Building Strong Brands, New York: The Free Press.

Arnould, E.J. and Price, L.L. (1993), "River magic: Extraordinary experience and the extended service encounter," Journal of Consumer Research, 20, 1, pp. 24-45.

Baker, S.M. and Martin, M.C. (2000), "The meaning of exchange in a sports card subculture of consumption," Research in Consumer Behavior, 9, pp. 173-196.

Belk, R.W. (1988), "Possessions and the extended self," Journal of Consumer Research, 15, 2 (September), pp. 139-168.

Bitner, M.J. (1995), "Building service relationships: It's all about promises," Journal of the Academy of Marketing Science, 23, 4, pp. 246-251.

Cohen, J. and Cohen, P. (1983), Applied Multiple Regression/Correlation Analysis for the Behavioral Sciences, 2nd edn., Hillsdale, NJ: Lawrence Erlbaum Associates.

Celsi, R.L., Rose, R.L. and Leigh, T.W. (1993), “An exploration of high-risk leisure consumption through skydiving," Journal of Consumer Research, 20, 1, pp. 1-23.

Dodson, K.J. (1996), "Peak experiences and mountain biking: Incorporating the bike into the extended self," Advances in Consumer Research, 23, pp. 317-322.

Dwyer, F.R., Schurr, P.H. and Oh, S. (1987), "Developing buyer-seller relationships," Journal of Marketing, 51, 2, pp. 11-27.

Fornell, C. and Larcker, D.F. (1981), "Evaluating structural equation models with unobservable variables and measurement error," Journal of Marketing Research, 18, 1, pp. 39-50.

Fournier, S. (1998), “Consumers and their brands: Developing relationship theory in consumer research," Journal of Consumer Research, 24, 4, pp. 343-373.

Fournier, S. (2001), "Preventing the premature death of relationship marketing: Take two," 10th Anniversary Conference of the Market Academy, Stockholm University.
Gardner, B.B. and Levy, S.J. (1955), "The product and the brand," Harvard Business Review 33, 2, pp. 33-39.

Gerbing, D.W. and Anderson, J.C. (1988), “An updated paradigm for scale development incorporating unidimensionality and its assessment," Journal of Marketing Research, 25, 2, pp. 186-192.

Grubb, E.L. and Grathwohl, H.L. (1967), "Consumer self concept, symbolism, and market behavior: A theoretical approach," Journal of Marketing, 31, 4, pp. 22-27.

Hartline, M.D. and Ferrell, O.C. (1996), "The management of customer-contact service employees: An empirical investigation," Journal of Marketing, 60, 4, pp. 39-51.

Holt, D.B. (1995), "How consumers consume: A typology of consumption practices," Journal of Consumer Research, 22, 1, pp. 1-16.

Keller, K.L. (1998), Building, Measuring, and Managing Brand Equity, Upper Saddle River, NJ: Prentice-Hall Inc.

McAlexander, J.H. and Koenig, H.F. (2001), "University experiences, the student-college relationship, and alumni support," Journal of Marketing for Higher Education, 3, 10, pp. 21-43.

McAlexander, J.H., Koenig, H.F. and Schouten, J.W. (2004), "Building a university brand community: The long-term impact of shared experiences," Journal of Marketing for Higher Education, 14, 2, pp. 61-79.

McAlexander, J.H. and Schouten, J.W. (1998), "Brandfests: Servicescapes for the cultivation of customer commitment," in Sherry Jr JF (ed.), Servicescapes, Newbury Park: Sage, pp. 377-401.

McAlexander, J.H., Schouten, J.W. and Koenig, H. F, (2001), "Building brand community," Journal of Marketing, 66, 1, pp. 38-54.

Muniz, A. and O’Guinn, T.C. (2001), "Brand community," Journal of Consumer Research, 27, 4, 412-432.

Nunnally, J.C. (1978), Psychometric Theory, 2nd edn., New York: McGraw-Hill Book Company.

Price, L.L. and Arnould, E.J. (1999), "Commercial friendships: Service provider-client relationships in context," Journal of Marketing, 63, 4, pp. $38-56$.

Schouten, J.W. and McAlexander, J.H. (1995), "Subcultures of consumption: An ethnography of the new bikers," Journal of Consumer Research, 22, 4, pp. 43-61.

Schouten, J.W., McAlexander, J.H. and Koenig, H.F. (2005), "Transcendent experience and the brand community," Working paper, University of Portland.

Sherry Jr, J.F. (1983), "Gift-giving in anthropological perspective," Journal of Consumer Research, 10, 2, pp. $157-168$. 